\title{
How Effective İs The Nigerian Senior School Agricultural Science Curriculum? A Survey Of Evidence From Content Development To Product
}

\author{
Akanmu, Samson Akinwande, M.Ed. \\ Department of Curriculum and Instruction, \\ Federal college of Education, Okene, Kogi State, Nigeria \\ Adejare Solomon Olorundare PhD \\ Johnson Uphai, PhD \\ Department of Science Education, Faculty of Education, \\ University of Ilorin, Ilorin. Nigeria
}

doi: 10.19044/esj.2016.v12n4p395 URL:http://dx.doi.org/10.19044/esj.2016.v12n4p395

\begin{abstract}
Agricultural science, a vocational subject in Nigerian senior schools is yet to meet its objectives due to various challenges. Consequently, the performance of students in the subject is relatively poor. This study examined the effectiveness of the Nigerian senior school agricultural science curriculum. 255 teachers and 255 students were engaged for the study. Teachers' Curriculum Evaluation Instrument (TCEI) and Agricultural Achievement Test (AAT) were used for data collection. Data were analysed using descriptive statistics. Findings from the study show that $86 \%$ of the teachers perceived the agricultural science curriculum content were suitable for students' performance, the instructional facilities for agricultural science teaching in schools are not adequately available and agricultural science curriculum implementation was confronted with several challenges. Student performance in agricultural science was poor as about $51 \%$ had credit pass in the administered test and $49 \%$ failed the test. Using the CIPP frame work, this study concluded that the context (content) is suitable, input (instructional facilities) is deficient, process (implementation) is highly deficient and consequently, the (product) student performance in agricultural science is poor. It is recommended that among others that concerned stakeholders should adequately provide instructional facilities, ensure their adequacy and also supervise their judicious utilization.
\end{abstract}

Keywords: Agricultural science, content, curriculum, senior secondary, Nigeria 


\section{Introduction}

The Nigerian agriculture had suffered neglect for decades due to the discovery of oil. However, the sector still contributes significantly to the nation's gross domestic product. As highlighted by Adegboye (2004), agriculture contributes more than 30 percent of the country's annual Gross Domestic Product (GDP), employs about 70 percent of the labour force, accounts for over 90 percent of the nation's non-oil exports and provides over 80 percent of the country's food resources.

Despite the importance of agriculture such as food, clothing, homes, even human traditions and values all come from agriculture Ronald, (1999), the study of agriculture in Nigerian schools are faced with a myriads of challenges. Onuekwusi and Okorie (2008) reported low students' performance in agriculture science in Nigeria in the recent years and attributed this low performance to number of factors which among others are: lack of adequately trained youths in agriculture to take up farming as a career (Olusanya, 1990; Olaitan \& Uwadiae, 1993).

In the National Policy on Education, Agriculture is one of the subjects offered in Junior and Senior Secondary Schools, as a pre-vocational elective and vocational elective respectively (Federal Republic of Nigeria, 2013). The curriculum content of the senior school level was structured to focus on three major areas: production (food production), projection (agronomy and forestry) and economics (agricultural economics and farm management). 'Guided Discovery' a method that lays emphasis on learning by doing was recommended in the curriculum to enable the students explore and harness the agricultural resources within their local environment. This will help students in food production and other agricultural products for themselves and their community (Nigerian Educational Research and Development Council [NERDC], 2012).

The overall objective of the revised curriculum is to provide students with adequate knowledge and skills that will enable them to discover their talents and enrich agricultural science education in Nigeria (NERDC, 2012). Specifically, the objective of senior secondary Agricultural education is to:

1. stimulate and sustain students interest in Agriculture;

2. impart functional knowledge and practical skills in agriculture to students;

3. prepare students for further studies in area of agriculture; and

4. prepare students for profession in Agriculture (NERDC, 2012).

Ikeoji et al. (2007) maintained that the basic goal of the National Policy on Education is to make education both practical and useful. It has also been observed that vocational education originated out of the need for 
the system to make its products useful to themselves and to the society (Ikeoji, 1999).

Even though agriculture is a vocational elective at senior secondary, the performance of students in the subject and the sector has not improved. Ikeoji and Agwubike (2006) noted that graduates of vocational agriculture in senior secondary schools in Nigeria have often not been able to take up their responsibility in paid jobs at the completion of their secondary education, thus, defeating the goals of changing agriculture to a vocational subject at secondary school level in Nigeria.

Oluwadaisi (2010) conducted a study to evaluate the agricultural science curriculum at secondary school using the Stufflebeam's CIPP model. The researcher adopted only the context, input and process variables of CIPP model. The researcher involved teachers only as the respondents for the study. However, this present study evaluated effectiveness of the revised agricultural science curriculum using the four indicators of the model, this implies that human subject such as teachers and students are involved as respondents from whom responses were elicited on the four indicators of the CIPP model. This is necessary since a complete evaluation should also include the outcome of the implementation process.

Daluba (2013) used the Agricultural Science Achievement Test' (ASAT) to examine the teaching method of agricultural science as it affects students' agricultural achievement. The researcher's attention was on demonstration but, he ignored other pedagogic approaches that could enhance the curriculum implementation.

This present study bridges the information gap in preceding studies by evaluating the agricultural science curriculum holistically from the teachers' perspective. In the present study, all the dimensions of the curriculum including the content suitability as perceived by the teachers, the instructional facilities availability and adequacy, implementation and challenges of teachers' implementation of the curriculum were considered. This is as a result of the teachers' central role in ascertaining the appropriateness of the curriculum to contribute substantially to meeting the nation's 2020 goal in the globalized economy.

The main purpose of this study was to see how effective is the Nigerian senior school agricultural science curriculum through a survey of evidence from content development to output. Specifically, the study through the perception of the teachers determined:

i. if the content of the curriculum would assist in achieving the curriculum objectives;

ii. the availability and adequacy of instructional facilities for agricultural science teaching; 
iii. the approaches used by the teachers to implement the agricultural science curriculum; and

iv. the performance of the Senior School Students in Agricultural Science in the study area.

\section{Materials and Methods}

This study is a descriptive research of the survey type. Data were collected from the respondents with the use of a structured questionnaire. The study involved 255 teachers of Agricultural science at the Senior School level in Kogi West Senatorial District of Kogi State, Nigeria. The Senatorial District is made up of seven local government areas: Kabba/Bunu, Ijumu, Mopa/Muro, Yagba East, YagbaWest, Kogi and Lokoja local government area. For the purpose of this study, two research instruments were administered to elicit responses from both the teachers and students. The instrument were:

(i) Teachers' Curriculum Evaluation Instrument (TCEI)

(ii) Agricultural achievement test (AAT)

The instrument administered to the teacher consist of two major sections. Section A consists of statements on agricultural science teacher's personal characteristics, while Section B consists of statements on teacher's evaluation of the curriculum content (context), instructional facilities available (input), and implementation strategies (process) using a four point Likert scale. Agricultural achievement test (AAT) were administered to the students to elicit information on their performance based on the product content of the CIPP model used for the study. Data collected were analysed using descriptive statistics such as mean, mode and frequency count.

\section{Results and Discussion}

Research question 1: How do the agricultural science teachers perceive the content of the agricultural science curriculum?

Table 1 shows that on an average, about 86 percent of the agricultural science teachers perceived that the agricultural science curriculum by NERDC is suitable to enhance student's performance in the subject. Explicitly, 84 percent of the teachers agreed that the NERDC agricultural science curriculum is readily available to agricultural science teachers. About 94 percent of the respondents claimed to be familiar with the contents and objectives of the senior school agricultural science curriculum. A total of 91 percent of the respondents agreed that the agricultural science curriculum is adequate to meet its objectives. About 89 percent of the teachers agreed that the spiral approach of topics presentation in the curriculum is appropriate. Majority of the teachers (92 percent) agreed that the content of the 
agricultural science curriculum is adequate to prepare students for career in agriculture.

This implies that majority of the teachers agreed that the curriculum objectives and content are suitable and adequate. This finding was in line with other studies such as Oluwadaisi, (2010), who had earlier found that about $69 \%$ of agricultural science teachers agreed with the view that the content of the agricultural science curriculum is appropriate for the learners.

Table 1: Agricultural science content suitability as perceived by teachers

\begin{tabular}{|c|c|c|c|}
\hline $\mathrm{S} / \mathrm{N}$ & Statement & Agree \% & Disagree\% \\
\hline 1 & $\begin{array}{l}\text { NERDC agricultural science curriculum } \\
\text { is readily available to all agric-teachers } \\
\text { in senior schools }\end{array}$ & 84 & 16 \\
\hline 2 & $\begin{array}{l}\text { I am familiar with the contents and } \\
\text { objectives of the senior school } \\
\text { agricultural science curriculum }\end{array}$ & 94 & 6 \\
\hline 3 & $\begin{array}{l}\text { The contents of the agricultural science } \\
\text { curriculum is adequate to meet its } \\
\text { objectives }\end{array}$ & 91 & 9 \\
\hline 4 & $\begin{array}{l}\text { The nine (9) major themes of the } \\
\text { agricultural science curriculum at senior } \\
\text { schools is adequate for its objectives }\end{array}$ & 89 & 11 \\
\hline 5 & $\begin{array}{l}\text { The spiral approach of presentation of } \\
\text { the topics in the curriculum for } \\
\text { agricultural science at senior school } \\
\text { levels is appropriate }\end{array}$ & 89 & 11 \\
\hline 6 & $\begin{array}{l}\text { The SSS curriculum for agricultural } \\
\text { science for senior schools provides for } \\
\text { contents, performance objectives, } \\
\text { teachers' and learners' activities, } \\
\text { teaching and learning materials and } \\
\text { evaluation guide }\end{array}$ & 87 & 13 \\
\hline 7 & $\begin{array}{l}\text { The SSS curriculum for agricultural } \\
\text { science for senior schools is rigid and } \\
\text { does not encourage teachers to enrich the } \\
\text { contents with relevant materials and } \\
\text { information from their immediate } \\
\text { environment }\end{array}$ & 76 & 24 \\
\hline 8 & $\begin{array}{l}\text { The SSS curriculum for agricultural } \\
\text { science for senior schools does not show } \\
\text { agricultural science and its inter- } \\
\text { relationship with other subjects }\end{array}$ & 82 & 18 \\
\hline 9 & $\begin{array}{l}\text { The use of local materials in teaching and } \\
\text { learning of agricultural science is not } \\
\text { recognised in the SSS curriculum for } \\
\text { agricultural science for senior schools }\end{array}$ & 80 & 20 \\
\hline 10 & $\begin{array}{l}\text { The SSS curriculum for agricultural } \\
\text { science for senior schools has been able to } \\
\text { integrate scientific concepts in to the } \\
\text { teaching of the subject }\end{array}$ & 88 & 12 \\
\hline 11 & $\begin{array}{l}\text { Evaluation technique employed in the } \\
\text { SSS curriculum for agricultural science } \\
\text { for senior schools does not reflect its } \\
\text { contents }\end{array}$ & 74 & 26 \\
\hline
\end{tabular}




\begin{tabular}{|c|c|c|c|}
\hline 12 & $\begin{array}{l}\text { The contents of SSS curriculum for } \\
\text { agricultural science for senior schools are } \\
\text { adequate to prepare students for further } \\
\text { studies in agriculture }\end{array}$ & 92 & 8 \\
\hline 13 & $\begin{array}{c}\text { The content of the SSS curriculum for } \\
\text { agricultural science for senior schools is } \\
\text { adequate to prepare students for } \\
\text { occupation and career in agriculture. } 2\end{array}$ & 90 & 10 \\
\hline 14 & $\begin{array}{l}\text { The recommended } 3 \text { trades (animal } \\
\text { production, agronomy and forestry, } \\
\text { agricultural economics and farm } \\
\text { management) in the SSS curriculum for } \\
\text { agricultural science for senior schools } \\
\text { needs to be revised in line with modern } \\
\text { trend }\end{array}$ & 92 & 8 \\
\hline $\begin{array}{c}\text { \% average } \\
\text { Mean }\end{array}$ & & 86 & 14 \\
\hline
\end{tabular}

Research question 2: To what extent are the instructional facilities available and adequate for the implementation of the agricultural science curriculum?

Table 2 shows that only $30 \%$ of the schools visited had farm space for practical farming and only $5 \%$ and $35 \%$ of this available farm space were respectively rated as very adequate and adequate accordingly. For farm tools, $90 \%$ of the schools visited had farm tools and only $10 \%$ had it very adequate, $60 \%$ had with just adequate and $30 \%$ had it as not adequate respectively. About $30 \%$ of the sampled schools have farm equipment/machinery such as sprayers, tractor, Gunter chain, theodolite, compass while such equipment are not available in the remaining $70 \%$. About $5 \%$ of the schools have ruminant and non-ruminant animals while none of the schools have a fish pond as an instructional facility. A total of $40 \%$ have orchard and $20 \%$ have agricultural science laboratory.

Oluwadaisi (2010) also found that, even though instructional facilities are available to an extent, they are insufficient to meet the curriculum objectives in Agricultural science. The descriptive analysis in table 2 also shows that even though some instructional facilities for agricultural science teaching in schools are not readily available as required they were insufficient where they were available and it can thus be implied that it is availability, adequacy and judicious use of agricultural instructional facility that could strongly or positively influence students' performance in the subject. 
Table 2: Instructional facilities evaluation using descriptive statistics

\begin{tabular}{|c|c|c|c|c|c|c|}
\hline \multirow[t]{2}{*}{$\mathrm{S} / \mathrm{N}$} & \multirow{2}{*}{$\begin{array}{l}\text { Instructional } \\
\text { facilities }\end{array}$} & \multicolumn{3}{|c|}{ Availability } & \multicolumn{2}{|c|}{ Adequacy } \\
\hline & & $\begin{array}{c}\text { Available } \\
\%\end{array}$ & $\begin{array}{c}\text { Not } \\
\text { available \% }\end{array}$ & $\begin{array}{c}\text { Very } \\
\text { adequate \% }\end{array}$ & Adequate \% & $\begin{array}{c}\text { Not- } \\
\text { adequate } \\
\%\end{array}$ \\
\hline 1. & Farm space & 30 & 70 & 5 & 35 & 60 \\
\hline 2 & $\begin{array}{l}\text { Farm tools such } \\
\text { As hoe \& }\end{array}$ & 90 & 10 & 10 & 60 & 30 \\
\hline 3. & $\begin{array}{l}\text { cutlass } \\
\text { Farm } \\
\text { equipment } \\
\text { /machinery } \\
\text { such as } \\
\text { sprayers, } \\
\text { tractor, Gunter } \\
\text { chain, } \\
\text { theodolite, } \\
\text { compass etc }\end{array}$ & 30 & 70 & NA & NA & NA \\
\hline 4. & $\begin{array}{l}\text { Ruminant } \\
\text { animal such as } \\
\text { goat and sheep }\end{array}$ & 5 & 95 & NA & NA & NA \\
\hline 5. & $\begin{array}{c}\text { Non-ruminant } \\
\text { such as rabbit, } \\
\text { pig and poultry } \\
\text { birds }\end{array}$ & 5 & 95 & NA & NA & NA \\
\hline 6. & Fish pond & 0 & 100 & NA & NA & NA \\
\hline 7. & Orchard & 40 & 60 & NA & NA & NA \\
\hline 8. & $\begin{array}{l}\text { Agric- } \\
\text { laboratory }\end{array}$ & 20 & 80 & NA & NA & NA \\
\hline
\end{tabular}

Key: adequacy of facility: Farm space: greater than $50 \mathrm{~m}$ by $2 \mathrm{~m}$ to a student (very adequate), about $50 \mathrm{~m}$ by $2 \mathrm{~m}$ to a student (adequate) and less than $50 \mathrm{~m}$ by $2 \mathrm{~m}$ to a student (not adequate). Farm tool (hoe and cutlass): each student has access to more than one hoe and cutlass (very adequate), each student has access to one hoe and cutlass (adequate) access to a hoe and cutlass by two or more student (not adequate).

\section{Research question 3: What are the teachers' perception of the implementation approaches designed for the agricultural science curriculum?}

Table 3 show that on the average 82 percent of the respondents agreed that the implementation methods and process recommended by the agricultural science curriculum was appropriate. Further findings from the study show that 87 percent of the respondents agreed that guided discovery with emphasis on learning by doing as recommended in the agricultural science curriculum at senior school levels was also appropriate. A total of 72 percent agreed that the agricultural science at senior school levels encourages students to explore agricultural resources in their local environment to produce food and agricultural product for themselves. About 53 percent of the respondent perceived that the agricultural science class hours was 
insufficient for subject teaching and practical. About 97 percent of the respondents agreed that there is need for regular evaluation of students by teachers in other to accesses the strength and weakness of the curriculum. About 93 percent of the respondents agreed that the arrangement of the topics in the curriculum are appropriate and easy to implement.

Table 3: Teachers' perception of the implementation process of the curriculum

\begin{tabular}{|c|c|c|c|}
\hline $\mathrm{S} / \mathrm{N}$ & Statement & Agree \% & Disagree \% \\
\hline 1 & $\begin{array}{l}\text { Guided discovery with emphasis on } \\
\text { learning by doing as recommended in } \\
\text { the agricultural science curriculum at } \\
\text { senior school levels is appropriate. }\end{array}$ & 87 & 13 \\
\hline 2 & $\begin{array}{l}\text { The agricultural science at senior } \\
\text { school levels does not encourage } \\
\text { students to explore agricultural } \\
\text { resources in their local environment to } \\
\text { produce food and agricultural product } \\
\text { for themselves }\end{array}$ & 28 & 72 \\
\hline 3 & $\begin{array}{l}\text { The agricultural science class hours is } \\
\text { sufficient for subject teaching and } \\
\text { practical }\end{array}$ & 47 & 53 \\
\hline 4 & $\begin{array}{l}\text { Process and product techniques of } \\
\text { evaluation are recommended in the } \\
\text { curriculum for assessing students' } \\
\text { specific projects is adequate }\end{array}$ & 73 & 27 \\
\hline 5 & $\begin{array}{l}\text { Suggested activities in the curriculum } \\
\text { designed to enhance psychomotor } \\
\text { skills development in agriculture is } \\
\text { appropriate. }\end{array}$ & 85 & 15 \\
\hline 6 & $\begin{array}{l}\text { In-service training for teachers are } \\
\text { necessary to enhance the teaching of } \\
\text { the subject }\end{array}$ & 97 & 3 \\
\hline 7 & $\begin{array}{l}\text { The agricultural science curriculum } \\
\text { for senior school can be easily } \\
\text { translated and interpreted by } \\
\text { agricultural teachers. }\end{array}$ & 96 & 4 \\
\hline 8 & $\begin{array}{l}\text { There is need for regular evaluation } \\
\text { of students by teachers in other to } \\
\text { accesses the strength and weakness } \\
\text { of the curriculum }\end{array}$ & 97 & 3 \\
\hline 9 & $\begin{array}{c}\text { It is good for agricultural science } \\
\text { teachers to handle classroom } \\
\text { discussion and activities } \\
\text { objectively }\end{array}$ & 97 & 3 \\
\hline 10 & $\begin{array}{l}\text { Students are expected to comment } \\
\text { freely about difficult topics in the } \\
\text { subject during lessons }\end{array}$ & 97 & 3 \\
\hline 11 & $\begin{array}{l}\text { The arrangement of the topics in } \\
\text { the curriculum are appropriate and } \\
\text { easy to implement }\end{array}$ & 93 & 7 \\
\hline \%Mean & & 82 & 18 \\
\hline
\end{tabular}




\section{Research question 4: What is the performance of the Senior School} Students in Agricultural Science?

As revealed in figure 1 , about $4 \%$ of the students had A grade (75 percent and above) in the administered test; $13 \%$ had $\mathrm{B}$ grade (6574percent), 34\% had $\mathrm{C}$ grade (50-65 percent), 17\% had the $\mathrm{P}$ grade (40-49 percent) and 32\% had the F-grade (below 40 percent). This figure further revealed that only about $51 \%$ had credit pass in the administered test and $49 \%$ failed the test. This finding agrees with those of Mamman (2000); Egun (2007); Duze (2008) and Daluba (2013) who earlier reported poor performance of students in agricultural science. This shows that a lot is still needed to improve agricultural science performance in schools.

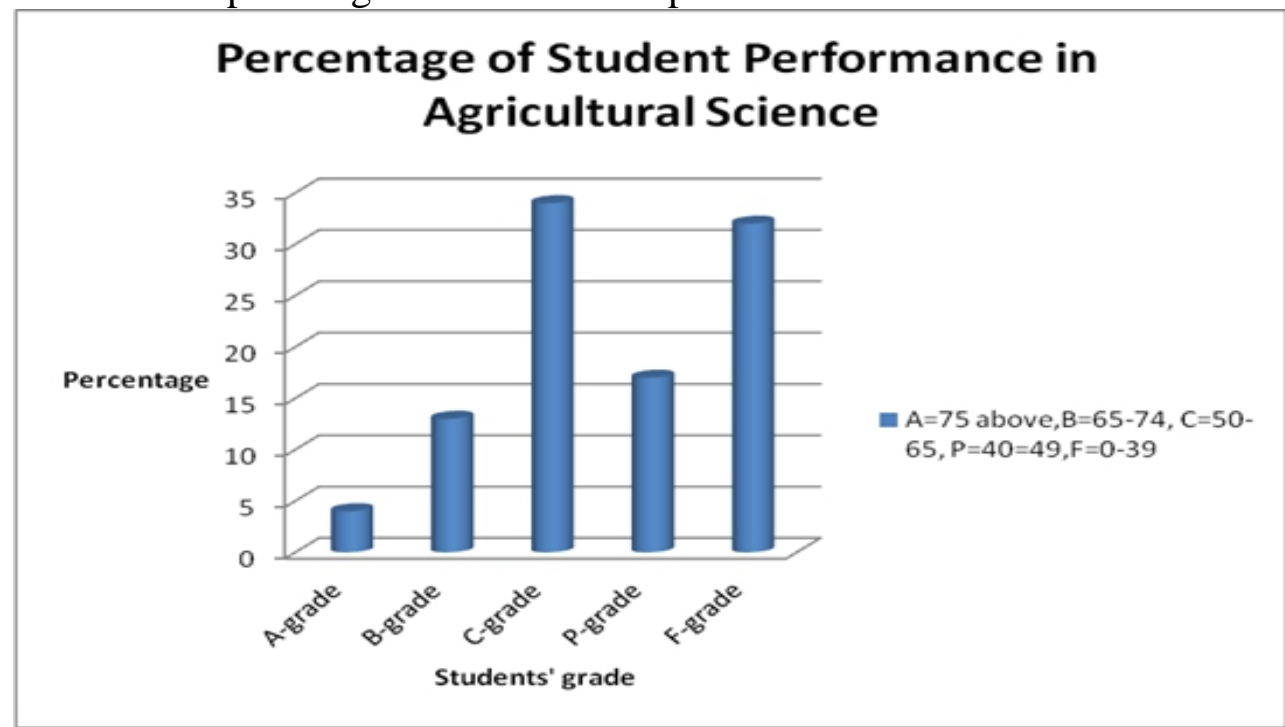

Figure 1: Chart showing student's Agricultural science performance from AAT Test.

\section{Conclusion}

Agricultural Science Curriculum

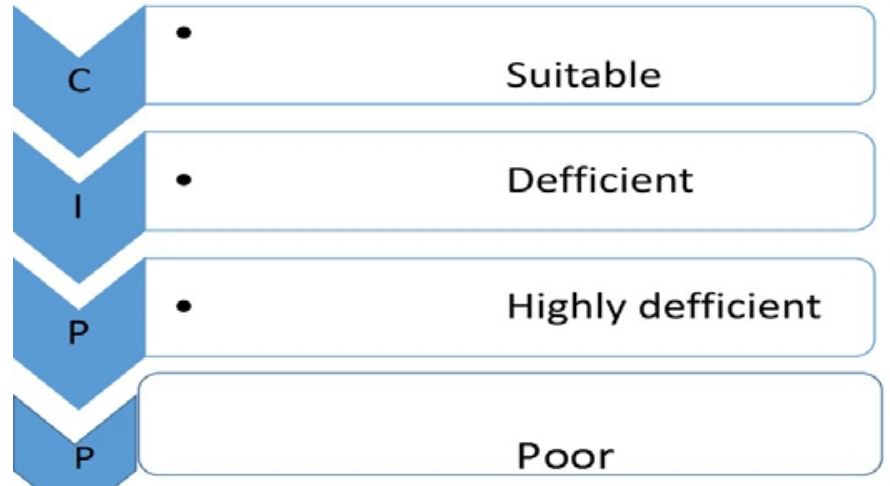

Figure 2: The agricultural science curriculum evaluation on CIPP framework 
Conclusively, using the CIPP frame work as typified in figure 2, this study concluded that the context (content) is suitable, input (instructional facilities) is deficient, process (implementation) is highly deficient and consequently, the (product) student performance in agricultural science is poor. Efforts should be made at addressing the deficient indicators on the framework. This study recommend that:

1. Government and school proprietors should adequately provide instructional facilities, ensure their adequacy and also supervise their judicious utilization;

2. Government and school proprietors should ensure that teachers handling the subject are qualified professionals in the specific area of agricultural science;

3. Non-governmental organization (NGOs) should assist schools in the provision of instructional facilities to aid teaching of the subject; and

4. Agricultural counselling should be available at foundational school level to encourage young learners to pick up agriculture as a profession.

\section{References:}

Adegboye, R. O. Land, Agriculture and Food security in Nigeria. 3rd Faculty Lecture, Faculty of Agriculture, University of Ilorin. 25/2/2004

Daluba, N. E. (2013). Effect of demonstration method of teaching on students' achievement in agricultural science, World Journal of Education, 2013: 3 (6), 1-7. Retrieved from www.sciedu.ca/wje 20 March, 2014

Duze, C. O. Falling standard in education: An empirical evidence in Warri Metropolis. Paper presented at the 2008 Annual Conference of the Faculty of Education, Nnamdi Azikiwe University, Awka. July 28th- $1^{\text {st }}$ August, 2008. Education, 2008: 31 (2), 7-11.

Egun, A. C. Reducing teacher's instructional differentials in identified content area of agricultural science syllabus of senior secondary school for better understanding in Nigeria. Journal of Social Sciences, 2007: 15 (2), 141-145.

Federal Republic of Nigeria. National policy on Education. Yaba-Lagos, Nigeria NERDC Press: 2013

Ikeoji, C. N, Agwubike, C. C. \& Disi, J. O. Perceptions of head agricultural science teachers regarding problems and challenges of vocational agriculture delivery in secondary schools in Delta State, Nigeria. Electronic Journal of Science Education, 2007: 11 (2), Retrieved from http://ejse.southwestern.edu on $12 / 02 / 14$ 
Ikeoji, C. N. \& Agwubike, C. C. Problems facing new agricultural science teachers in Delta State. European Journal of Scientific Research, 2006: 13 (2), $229-237$.

Ikeoji, C. N. Making senior secondary school agriculture truly vocational: A paper presented at the international conference on crucial issues on Nigerian/African education, University of Nigeria Nsukka 15-18 April., 1997

Mamman, M. G. Teacher education and teacher effectiveness. Journal of Teachers and Teaching, 2000: 1 (2), 25-29.

Nigerian Educational Research and Development Council (NERDC Senior Secondary School e-Curriculum Agricultural Science for SS 1 - SS 3: 2012. Available at www.nerdc.ng. Retrieved 07/10/2014

Olaitan, S. O. \& Uwadiae. S. A. Developing curriculum in agriculture. In: Curriculum development in Nigeria. Ivowi, U.M.O. (Ed.). Ibadan. Sam Bookman. 1993

Olusanya, P. O. Socio economic aspects of rural-urban migration in western Nigeria. In: O. Otite \& C. Okali, Readings in Nigeria rural society and rural economy (pp. 227-252). Ibadan. Heinemann educational Books Limited.: 1990

Oluwadaisi, R. Y. Evaluation of agricultural science curriculum in senior secondary schools in Ilorin Metropolis. (Unpublished M. Ed Thesis) University of Ilorin, Ilorin, Kwara State, Nigeria. 2010

Onuekwusi, G. C. \& Okorie, L. Attitude of secondary school students in Abia State towards career in Agriculture. Agricultural Journal, 2008: 3 (2), 102-106.

Ronald, L. H. Perceptions of students and teachers regarding agriculture in Leflore County, Mississippi. M.Sc. thesis in agricultural education submitted to College of Agriculture, Forestry, and Consumer Sciences, West Virginia University, Morgantown, West Virginia:1999 